E DIT ORIAL

\title{
Vivendo e aprendendo
}

O prof. Jaime Aparecido Cury da Faculdade de Odontologia de Piracicaba/Unicamp relatou que, entre 2001 e 2003, a Odontologia brasileira produziu mais artigos do que em todo o século XX. Assinala que esta mudança ocorreu em função dos melhores critérios de avaliação adotados pelos órgãos reguladores e pelo aumento de pesquisadores no país.

O expressivo número de 8.000 pós-graduados com título de doutor formados no ano de 2003 atesta que o país caminha para a valorização da pesquisa e do ensino de pós-graduação. Esse número também se traduz em mais artigos, mais pesquisas, mais linhas de trabalho e, portanto, a busca por melhorias na pós-graduação no país.

É indiscutivel que a qualidade dos trabalhos científicos produzidos no país tenha galgado passos largos. Entretanto, grande parte dos artigos e das pesquisas realizados no Brasil e fora dele acaba não sendo aproveitada (citação por pares) e/ou divulgada nos meios transmissores. Uma das razões para isso é que os artigos provenientes de teses, dissertações ou outras pesquisas e experiências clínicas relevantes são enviados para periódicos não indexados ou apenas divulgados localmente. Cabe aqui ressaltar que todo órgão divulgador tem a sua importância, portanto seria interessante que todos buscassem a indexação em uma base de dados. Atravessando esse processo, esses artigos e pesquisas específicos poderiam se valer das facilidades da Internet para serem conhecidos nos mais longínqüos rincões de ciência e prática clínica.

Outro entrave nas sitações por pares desses materiais deve-se ao fato de que, mesmo publicado, a diversidade metodológica tem atrapalhado a comparação entre estudos de temas semelhantes. Nesta edição da Revista Dental Press, o artigo de autoria de Cal Neto e Miguel, por exemplo, enfoca a questão dos testes de resistência de colagem de braquetes ortodônticos. Os autores alertam para a variabilidade metodológica como fator de dificuldade para a reunião de evidências científicas concretas que norteiam nosso exercício diário da Ortodontia.

A trajetória de nossa revista tem nos permitido amadurecer, ensinando a planejar, organizar e avaliar o conteúdo a ser transmitido à comunidade ortodôntica. Da mesma forma, ao assumirmos o papel de ortodontistas clínicos, o aprendizado e a ponderação adquiridos todo dia nos tornam melhores planejadores e executores.

Assim, também percebemos que as estratégias metodológicas de nossas pesquisas devem ser cautelosamente planejadas de forma a transformar a energia empregada na execução dos trabalhos em dados proveitosos aos nossos pares. Nos diversos graus de aprendizado, por vezes movidos pela empolgação da idéia, iniciamos a pesquisa sem o devido planejamento. Essa empolgação resulta às vezes em deficiências que farão com que a energia dispensada não seja tão recompensada quanto imaginávamos.

"Errar é humano e aprendemos com nossos erros", diz a máxima que nos ajuda e consola. Entretanto, a frase "melhor do que aprender com nossos erros é aprender com os erros de outrem" nos permitiria saltar degraus. Portanto, a exaustiva pesquisa e reflexão pelos erros já cometidos podem nos nortear para novos planejamentos cada vez melhores, fazendo que aproveitemos melhor cada dia e que saibamos aproveitar toda nova lição!

Adilson Luiz Ramos Editor 